\title{
Seed production of new cultivars of lucerne
}

\section{T. P. PAlmer}

Crop Research Division, DSIR. Lincoln

B. J, Donovan

Entomology Division, DSIR, Lincoln

\begin{abstract}
Multiplication of new cultivars of licerne must be rapid to keep abreast of new pests and diseases. The most important factor is to harvest high seed yields in the establishing year. Widespread use of alkali and leafcutting bees, and possible management of short-tongued bumblebees, should raise the pollination level to near maximum. Low seeding rates. early sowing, good early weed control, adequate pollination and insect pest control will be rewarding for seed growers, merchants and customers.
\end{abstract}

Key words: Seed production, Medicago sativa. Nomia melanderi. Megachile rotundata. pollination.

\section{INTRODUCTION}

Until the early 1970 s, Wairau was the main lucerne cultivar (Medicago sativa L.) recommended and grown in New Zealand. Local seed growers produced enough seed to supply demand in most years. In 197 1, bacterial wilt (Corynebacterium insidiosum (McCull) H. L. Jens) was recognized as a serious disease of lucerne in New Zealand (Close and Mulcock, 1972), and since then stem nematode (Ditylenchus dipsaci (Kuhn) Filipjev), blue-green luceme aphid (Acyrthosiphon kondoi Shinji), pea aphid (A. pisum Harris) and phytophthora root rot (Phytophthora megasperma Drechs) have been recognized as serious pests or diseases.

Cultivars resistant to some of these pests and diseases have been introduced from the USA and recommended for use. Saranac, resistant to bacterial wilt, was the first in 1974, followed by Washoe in 1976 and Iroquois, Pioneer 521. AS13 and AS13R, WL311 and WL3 18 in 1978, and Pioneer 524 in 1979. In 1978, Rere, which was bred in New Zealand and is resistant to blue-green aphid, was also approved for use (Dunbier and Palmer, 1978).

All these cultivars have been well received by farmers, but New Zealand seed production has been insufficient to supply the local demands. None of the cultivars now available are resistant to all the important pests and diseases listed above, and replacement cultivars can be expected during the next decade. Seed increase rates in New Zealand must be improved drastically if new cultivars are to be available and if New Zealand seed producers are to compete with USA or Australian seed producers in supplying seed of preferred cultivars.

With high multiplication rates, new cultivars will satisfy the market sooner, and the numbeı of generations of seed increase between breeder and grower can be reduced. Two grades of certified seed, basic and 1 st generation, should suffice for New Zealand seeds. This by itself should result in higher grade seed reaching the farmer.

Rapid multiplication hinges on reduced times from sowing to harvest, low seeding rates and high yields. These changes in seed-growing technique require greater inputs and skill from seed producers. A basic requirement for success is high profit for seed growers and merchants from early generation crops. Techniques are now available for achieving these objectives, and will be understood more fully within the next few years.

\section{FIRST-YEAR HARVEST}

Traditionally, lucerne seed has been harvested from established crops. However, lucerne can be sown in late September or early October to give a seed harvest in late March. This can halve the time of increase of new cultivars. It can also be combined with seed production in the USA, sowing in April and 
harvesting in September, to give two increases in one year. The development of Rere is an example. A sowing of $1 \mathrm{~kg}$ in Marlborough in October 1978 gave $250 \mathrm{~kg}$ in April 1979. Thirty $\mathrm{kg}$ of this sent to Idaho in early April is expected to return 5 tonnes of seed here by November 1979 , to give a 5000-fold increase in 14 months.

\section{WEED CONTROL}

Weeds are the main problem in first-year seed production. Lucerne seedlings do not compete well with weeds, and the operation will fail without adequate weed control from the time of sowing. Weeds $10 \mathrm{~mm}$ high are already competing with seedling lucerne, and become increasingly difficult to kill as they grow. Trifluralin applied before sowing controls many annual weeds from the time of lucerne seedling emergence. Because most applications of trifluralin usually do not control all susceptible weeds, and because some annual weeds are not susceptible to trifluralin, subsequent weed control by post-cmergencc spraying or cultivation will often be necessary. Crops sown in rows wider than $200 \mathrm{~mm}$ are more likely to be supressed by weeds, and will usually need early inter-row cultivation.

Besides reducing lucerne production, annual weeds pose problems at harvest. Weeds result in higher seed-dressing costs, and loss of lucerne seed which is dressed out when removing weed seeds. Widely spaced fathen (Chenopodium album agg.) plants will produce 100000 seeds weighing $100 \mathrm{~g}$. Spraying to kill infestations as low as 100 plants/ha would probably be profitable.

\section{ESTABLISHMENT}

The second most important step is to sow the crop on time. Sowing after 1 October will lead to lower yields, and sowing later than 1 November is likely to result in crop failure.

The stand should grow through to flowering in mid-Tanuary without a check. It must be growing vigorously through the whole of this period. Aphids can reduce the growth of young seedlings from emergence, so a systemic insecticidc should be sown with the seed to prevent early damage and protect the crop for its first 6 weeks (Palmer, 1977).

\section{SEEDING RATES AND ROW SPACINGS}

Low seeding rates lead to more rapid multiplication. Traditionally in New Zealand Lucerne was sown at 5 to $10 \mathrm{~kg} / \mathrm{ha}$. In the USA, lucerne seed fields are sown at about 0.75 $\mathrm{kg} / \mathrm{ha}$ in rows 500 to $1000 \mathrm{~mm}$ wide, and these low seeding rates have been shown to give higher yields.

In trials in Canterbury and Marlborough there have been no consistent differences in seed yields between seeding rates varying from 0.5 to $8 \mathrm{~kg} / \mathrm{ha}$, and with row spacings of 190, 380 and $750 \mathrm{~mm}$ (Wynn-Williams and Palmer, 1974).

Basically, the more widely spaced the lucerne plants, the larger each plant grows. The minimum number of plants necessary to give maximum seed yield is not known very exactly. For forage production, about 20 to 30 plants $/ \mathrm{m}^{\prime}$ are necessary (Palmer and Wynn-Williams, 1976), and the number for maximum seed yield will not be greater. Sowing I kg seed/ha gives 30 to 40 seeds $/ \mathrm{m}^{*}$, and with an average establishment rate of half the seed sown producing plants, this gives enough plants for maximum yields. Less seed costs less and gives high yields (which suits the grower) and gives higher multiplication rates (which suits the breeder).

Wider-spaced rows have not been shown to give higher seed yields in New Zealand. On present information, row spacing should be determined for convenience.

\section{POLLINATION}

For high seed yields, efficient pollination is necessary. New Zealand crops pollinated by wild bumblebees and honeybees can be expected to produce 50 to $100 \mathrm{~kg} / \mathrm{ha}$ on average in their first year. With saturation pollination with bumblebees, alkali bees or leafcutting bees, yields could exceed $500 \mathrm{~kg} / \mathrm{ha}$.

Lucerne seed will set only after the flowers are tripped by certain bee species. Pollinating bees should be manageable, so that sufficient bees will be available when and where they are wanted to pollinate all flowers. Native and introduced bees are common throughout most of New Zealand, but they differ markedly as lucerne pollinators. 


\section{NATIVE BEES}

About 40 species of native bees are known. At Lincoln numerous Lasioglossum sordidum (Smith) collect pollen from lucerne flowers that have already been tripped. These bees are thus ineffective as lucerne pollinators. In Central Otago two species of Leioproctus were seen tripping luccrne flowers in 1969, but aspects of their life cycle render unlikely their use as widespread pollinators of lucernc.

\section{HONEYBEES}

Honeybees are often very numerous in flowering lucernc, but flowers are seldom tripped because nectar can be taken without triggering the tripping mechanism However, in pollen shortages caused by 1 a ck of other flowers, honcybees sometimes trip lucerne flowers to obtain pollen.

\section{BumbiebeEs}

Of the four species of bumblebees in New Zealand, the short-tongued Bombus lerrestris (L.) is an excellent lucerne pollinator (Gurr, 1955; Macfarlane, 1976). B. terrestris fly in cold wet weather to collect pollen when other bees will not fly. Unfortunately, the number of bees in flowering lucerne is usually insufficient to pollinate most flowers. However, attempts to develop hives to increase bumblcbee populations have shown some possibility of success (Donovan and Wier, 1978).

Research at DSIR, Lincoin, promises to lead to designs for field-placed hives that will bc preferentially occupied by $B$. ferresfris (R. P. Macfarlanc, pers comm.). Success would give growers some measure of control over this valuable pollinator.

\section{Alkali Bees}

In the USA, alkali bees (Nomia melanderi Cockerell) are highly efficient lucerne pollinators. The species was established in New Zealand in 1971 (Donovan. 1975), and female bees pollinate lucernc here.

Females construct nests in moist soil. Adult bees are active from December to March, and during the remaining months fully fed larvae hibernate in the nests. Man-made nest sites that create soil moisture conditions acceptable to alkali bees can provide bees adjacent to lucerne.

Since 1972 the number of nests (one female per nest) has doubled annually to a total of 14000 nests in 1980. Given sunny warm weather and ample flowers, the bee increase rate is determined mainly by the suitability of the nest-site soil for nest construction. In nest sites with silty soil low in clay, and with protcction from rain and predatory birds, the bee populations have tripled annually.

Based on data from the USA, the bees from 14: 000 nests would provide adequate pollinalion for several hectares. At the present increase rate, alkali bces could be sufficiently numerous in 7 to 10 years to pollinate all New Zealand's lucerne seed crops.

Alkali bees are established in 10 man-made nest sites in Marlborough, and one cach in Alexandra and Banks Peninsula. All aspects of alkali bee nest-site construction, bee establishment and management have been resolved (Donovan, 1979) for Marlborough and Central Otago. Experimentation with soils in Canterbury is just beginning. Commercial exploitation of alkali bees is being initiated and a detailed booklet on all aspects of alkali bec use is available from DSIR, Lincoln.

In the western USA, nest sites with about 250 nests $/ \mathrm{m}$ ' provide sufficient bees to pollinate about 200 times that area of lucerne (Johansen et al.. 1978). Growers intending to use alkali bees should build onc or more nest sites with a total area one two-hundredths that of the lucernc to be pollinated. Care must be taken to allow for the area of lucerne on ncighbouring farms, because some alkali bees will pollinate beyond farm boundarics. If neighbours build alkali bee nest sites, then this factor will be cancelled.

\section{LEAFCUTTING BEES}

Leafcutting bees (Megachile rotundata (Fabricius) ) are widely used lucerne pollinators in the American Pacific Northwest, and in the western provinces of Canada. Female bees construct nests of joined lcaf pieces in holes about 100 to $150 \mathrm{~mm}$ long and $6 \mathrm{~mm}$ in 
diameter. Drinking straws sealed at one end, holes drilled in timber, or grooved boards stacked to form holes all provide suitable nest holes. Nest holes are housed in shelters which pprotect the nests from rain and wind, around or among lucerne seed fields.

The first New Zealand release of this important lucerne pollinator in 1971 (Donovan, 1975) was followed by disappointing propagation. Up to 1976 the number of' bee cells recovered after each season's nesting either approximately equalled the number released at the beginning of the season (1971 and 1974) or was as much as $40 \%$ less. Plywood shelters used up to 1976 were based on designs of plywood shelters used in North America. However, in 1977 many bees were housed in shelters of a wooden framework sheathed in durolite, a corrugated semi-clear roofing material. That season, leaf-cutting bees propagated by 1.45 times. In 1978 and 1979, with ail bees housed in durolite shelters, the propagation rates were 1.96 and 1.86 times, respectively.

Leafcutting bees will only fly and construct nests (and thus pollinate) in sunshine at an air temperature of $16^{\circ} \mathrm{C}$ or above. In durolite shelters the air temperature can be up to $9^{\circ} \mathrm{C}$ higher than the external temperature because of the glasshouse effect of the sun shining through the durolite. The higher internal air temperature stimulates female bees to flight when they would otherwise remain in their nests. Coupled with improvement in other factors which affect leafcutting bee propagation, the development of durolite shelters has assured that leafcutting bees will be usable commercially for lucerne pollination.

After the 1979 summer, the total numbes of cells had increased to 1.38 million. If the present propagation rate is maintained there will be sufficient leafcutting bees to pollinate all lucerne seed fields by the mid-1980s.

Bee propagation has been satisfactory in Taupo, Marlborough. Lincoln, valleys on Banks Peninsula and Central Otago. In favourable seasons, sheltered fields in most areas should be conducive to bee nesting, but many districts such as the Nelson area and much of Canterbury and Central Otago have not yet been adequately tested.
Ownership of most leafcutting bees has now passed to lucerne seed growers. In 1979 about 40 growers were tutored in all aspects of leafcutting bee management, and more growers will receive bees and management instructions in 1980. Commercial manufacture of leafcutting bee equipment is being organized.

Based on North American estimates of the pollinating efficiency of individual bees, about 50000 cells should be released per hectare for full pollination. Large durolite shelters have been designed which will accommodate the bees from at least 100000 cells, so one of these shelters will be needed for every 2 ha lucerne.

Detailed instrüctions on leafcutting bee management are available from DSIR, Lincoln.

In 1978, 0.5 ha of spring-sown Rere which was pollinated by bees from at least 50000 cells produced $202 \mathrm{~kg}$ of seed $51 / 2$ months after the field was sown. This equivalent perhectare yield of $404 \mathrm{~kg}$ was five times the mean yield from established lucerne fields without leafcutting bees. Other fields with many leafcutting bees have produced similar increased seed yields.

\section{INSECT PEST CONTROL}

Macfarlane and Pottinger ( 1976) recorded 15 insect species which reduced lucerne seed production by damaging flower buds, seeds and pods. The importance of insect damage to seed crops will probably become more apparent and more important when pollination levels increase. Little is known of lucerne insect pest control in New Zealand, but methods used in North America may prove valuable. When using insecticides extreme care must be taken to protect pollinating bees. Studies on insect pests now in progress should soon provide recommendations for insecticide use which will be compatible with the management and utilization of pollinating bees.

\section{HARVEST}

There has been no experimental work on lucerne harvesting methods, but the earlier the crop is harvested, the lower the risk of crop loss from late autumn storms. Waiting for the last seed to ripen may not always mean maximum yield. 


\section{SEED OF OTHER LEGUMES}

The concentrated pollination which can be achieved by alkali and leafcutting bees may give an earlier seed set, and so an earlier and more certain harvest.

Opinions also differ about windrowing or direct heading crops. From our experience in Canterbury, where harvest conditions are not as good as in Marlbrough, desiccating and direct heading has less risk than windrowing.

\section{CONCLUSION}

High seed yields from first-year crops provide rapid multiplication of new cultivars, good profits to seed growers, satisfaction to customers and improved competitive ability with foreign seed growers.

The essentials are adequate and early weed control, early sowing, low seeding rates, a high pollination level and control of insect pests

Use of alkali and leafcutting bees should become widespread within the next decade. Because of the different climatic requirements that favour propagation -of each species of bee, one may be of more use in certain districts than the other. Constraints on the increase in bee numbers may be imposed by inclement weather, the need to construct equipment, and the necessity for growers to learn to manage bees and equipment. Adoption of the use of these two bees, and likely use of short-tongued bumblebees, will place New Zealand growers in a strong position, because pollination up to the best of North American standards will greatly increase seed yields.

Even if the best agronomic procedures are followed, first-year seed yields will only be $100 \mathrm{~kg} / \mathrm{ha}$ without adequate pollination and insect pest control. However, if the proce dures for improving pollination as outlined in this paper are followed. seed yields should reach 400 to $500 \mathrm{~kg} / \mathrm{ha}$ in the first year.

\section{REFERENCES}

Close, K.: Mulcock, A. P., 1972. A'.\%. /l agric. Res. 15: $141-8$

Donovan. B. J., 1975. Proc. N.Z. Grassld Ass., 36: 123-8.

_ 1979. Proce I Vith Int.Symp. on Pollination. Md. Agric. Exp. Sta. Spec. Misc. Publ. 1: 257-268 Donovan. B. I.; Wier, S. S.. 1978. N.7. Jl agric. Res., 21: 733-56.

Dunbier, M. W.: Palmer. T. P., 1978. Aglink FPP 147. MAF. Wellington.

Gurr, L., 1955. N.Z. // sci. Technol.. A57: 300.

lohansen, C. A.: Mayer. D. F.: Eves. I. D., 1978. Melanderia, 28: 25-46.

Macfarlane, R. P.. 1976. In New Zeuland Insect Pests, pp. 221-9. Ed. D. N. Ferro. Lincoln College.

Macfarlane. R. P.: Poltinger, R. P., 1976. Proc. N.Z. Weed \& Pest Control Conf. 29: 19-22.

Palmer, T. P.. 1977. Ibid.. 30:173-6.

Palmer. T. P.; Wynn-Williams. R. B., 1976. N.Z. $/ /$ exp. Agric.. 4: $71-7$.

Wynn-Williams. R. B.: Palmer. T. P., 1974. Proc: Apron. Soc. N.Z. 4: 63.5 . 